\title{
Converted by un confit de canard: Political Thinking in the Novel Soumission by Michel Houellebecq
}

\author{
MARIE DEMKER \\ Gothenburg University, Department of Political Science/Faculty of Arts, Box 200, \\ SE 40530 Gothenburg, Sweden. Email: marie.demker@gu.se
}

From a certain perspective, literature is always political. Literature in a broad sense has been a source of uprisings and protest at least since Martin Luther nailed his theses on the door of the church in Wittenberg in 1517 - and probably much further back in history than that. Narratives are the most potent way to articulate both political praise and criticism within a given society. In his political satires, British author George Orwell reviled all kinds of totalitarianism and the idea of a socialist utopia. Swedish writer and journalist Stieg Larsson wrote explicitly dystopian crime stories targeting the Swedish welfare state. German novelist Heinrich Böll turned a critical eye on the development of the tabloid press and the use of state monitoring in German society. In the same tradition, Michel Houellebecq has been seen as a very provocative writer in his tone and in his use of political tools. He has articulated a nearly individual anarchist perspective combined with authoritarian and paternalistic views. In Soumission, Houellebecq uses the European idea of multiculturalism to explode our political frames from within. This article explores the perception of religion in Soumission, assesses the critique Houellebecq directs towards French society and European developments, and examines Houellebecq's perception of democracy and politics. The following questions are addressed: does Houellebecq's critique come from a classical ideological perspective? Does he describe any elements of an ideal society - even if only as the reverse of a presented dystopia? What kind of democracy does the text of Soumission support or oppose?

\section{Introduction}

Mockery, satire, irony and parody are only some of the styles that have been used in European history in the service of some political mission or other. Well-known examples include François Rabelais (1494-1553), Jonathan Swift (1667-1745) and Olof von Dalin (1708-1763). However, a political literary genre also exists that is closer to reality, in which the concepts of 'now' and 'then' can change places, and 
contemporary features can be twisted and redrawn to create a completely new dystopian alternative. Perhaps the best-known author of this genre is George Orwell (Eric Blair), whose novel 1984 has had lasting relevance, with its themes of Big Brother, surveillance and the idea of truth being promulgated by the state power. ${ }^{1}$ George Orwell has been the subject of several political analyses, both as a writer and as a political thinker. ${ }^{2,3}$ As a political scientist myself, I consider that with his book Soumission (Flammarion, 2015), Michel Houellebecq has simultaneously written a political dystopia and a political gospel.

For the sake of conciseness, I will omit a detailed discussion of the evident parallel between Soumission and the biblical story of Saul on his way to Damascus, which occurs in the book of Acts, in which Saul is converted by a meeting with the son of God. I will also omit the obvious parallel (which is directly touched upon in the text of Soumission itself) with the 1954 French novel Histoire d'O by Ann Desclos (pen name Pauline Réage), a tale about the pleasure of female submission. ${ }^{4}$ Rather, my contribution is to use a political science lens to identify and discuss some of the central political ideas and themes used in the novel. Using this technique, I will give an overview of the political universe presented by Houellebecq in this novel. ${ }^{5}$

The framework for the novel is a France where politicians have lost control over extremists and where only two sides eventually remain: the moderate Islamists and the French nationalists of the Front National. A university professor named François, who has a very barren private life and a not-so-successful academic life, must choose between submitting to an Islamic university regime or quitting his job and perhaps also his country. He chooses a life in the university, converts to Islam and is required to uphold certain interesting academic positions.

Soumission is like a kaleidoscope, in that one can pick a political theme and find examples of how Houellebecq uses it, and then see how he slightly displaces it until it shows up through another character. This fragmented repetition is the great value of the book, in my opinion. In this article, I concentrate on a number of aspects of Soumission that are provocative, thoughtful and/or imaginative from a political science viewpoint.

\section{About Resistance}

In 1942, the Vichy regime was installed in France. Vichy was a puppet of the Germans, although the French troops that were loyal to Vichy did not think so. The notion of the French Resistance in France - which was an underground movement opposing the Nazis and the Vichy regime - is still a powerful one. ${ }^{6}$ For a long time, having been part of the Resistance proved that one was on the 'right side', and any politician with no record of a Resistance past had little hope of a successful career. Soumission is reminiscent of a French novel from the 1940s or 1950s, as its prose reflects the gloomy mood of the years during and just after the Second World War. ${ }^{7}$ François describes his flat and his work as if he is upholding the legacy of the intellectual universe of Jean-Paul Sartre or Jean Genet. ${ }^{8}$ Of course, this Second World War mood shifts to a more contemporary one; however, I argue that, in this 
novel, Houellebecq betrays the memory of the Resistance, a memory that still evokes strong emotions in France.

François, the author's alter ego, initially considers resistance to the new regime and flight from a threatening civil war to be a possibility. He takes his very macho material objects (boots and car) and heads southwest, thinking of crossing the border into Spain. But in this lovely southwest part of France, where he has never been before, François finds all the traditions he considers to be genuinely French including the traditional French dish le confit de canard. He, himself, never actually eats this duck cooked in its own fat; however, its very presence makes him hesitate, and the opportunity to talk things over with an old friend and enjoy the food made by that friend's wife persuades François to stay for a while and consider his position. After an encounter with the Virgin Mary and her son Jesus Christ - in the form of a statue in a church - François decides to return to Paris. The encounter in the church is more a moment of desacralization than a spiritual meeting, but it ends up changing his course anyway. Weighing the presence of the Virgin Mary on the one hand and the memory of the confit de canard on the other, François decides to go with the duck. Materialistic and bodily pleasures are more important to François than the Christian gospel and the Virgin Mary. It can be said that here François has submitted to his instincts rather than to his academic spirit or moral principles. This assessment is further underpinned by a visit he makes to a monastery, where he becomes angry upon seeing a smoke detector in the ceiling. This incident leads him away from the gospel and from the possibility of religious resistance against Islam and the Muslim party that lies latent in the book. By this gesture, François acts as if his traditional religion, Catholicism, has lost its potency; Houellebecq also seems to imply more generally that religion, as a holy and sacred belief, has lost its force. All that remains is tradition, which has retained its rituals but now lacks any substance.

Thus, François is no Resistance hero, but rather the opposite: he is an individual man who, without moral objections, decides to submit to physical power. Furthermore, he does so because of his lack of stature, not because of any ideological views or arguments, moral underpinnings or genuinely personal convictions. François submits because submission will give him the pleasures and glory he wants, and because he has no other strong moral conviction to rely on. Here, Houellebecq echoes the French writer Albert Camus (1913-1960) and his character, Meursault, in L'Étranger, who happens to commit a murder just because he succumbs to his momentary instincts. ${ }^{9}$ Houellebecq echoes Camus in other passages of Soumission as well, with observations on the absurdity of human life. But where Camus leaves Sisyphus, in Le Myth de Sisyphe, rolling his stone up the mountain and being happy despite doing something that in itself brings no happiness, ${ }^{10}$ Houellebecq leaves François mainly looking forward to fulfilling all kinds of carnal desires, despite having been assigned the seemingly endless project of republishing the French novelist Joris-Karl Huysmans (1848-1907). ${ }^{11}$ I therefore argue that in Soumission, Michel Houellebecq betrays the entire concept of resisting immoral or evil regimes on the grounds of moral principles or for the common good. Of course, this is a 
politically provocative message, especially in France, with its memories of the Vichy regime and the Resistance movement.

\section{The Political Institutions}

The novel takes place in a near future in which the socialist president François Hollande has been re-elected in 2017 (which did not actually occur). ${ }^{12}$ In the subsequent election, the Islamic Front has joined forces with the left and centre-left to oppose the growing nationalist crowds supporting the Front National and their leader, Marine le Pen. Nevertheless, there are no convincing arguments as to why this odd alliance has come about. Houellebecq argues that the left has no defence against the moderate Islamists due to a leftist inclination towards anti-racism at any given moment. His argument rests on the view that 'leftists' and 'anti-racists' embrace the idea that a suppressed group cannot be criticized for the political position it assumes because this position is intrinsic to the suppressing societal structures. Houellebecq argues that an unwillingness to acknowledge any value conflict in religious values or national culture has blinded the liberal forces to the threats of religious fundamentalism. Although this argument is understandable, it is not convincing in describing how political power is distributed. Yes, there are individuals among the liberals and others on the left of the political scale who find it hard to admit that the political ideas embraced by some immigrant groups, minority groups or suppressed groups can be degrading for democracy. Such ideas can in fact undo some of the democratic victories that have been won, for example, in relation to gender equality and freedom of thought. However, first, the groups in question are inherently small and rarely have any representation in political decision-making bodies; and second, such groups would have severe difficulty winning the voters' approval in a democratic election. ${ }^{13}$ On the contrary, the groups that are currently winning voters' approval are those that affirm nationalist views. ${ }^{14}$ The third obstacle would be the jurisdiction in the European Union (if the French tribunals were to unexpectedly submit to this regime), which would oppose most of the propositions that Houellebecq writes about in the novel. Even though the European Union has proven to be more of a paper tiger than a real one - for example, regarding Hungary and Poland and their toughening laws on freedom of the press and on education Houellebecq's view on political development goes further than anything in real life, and bluntly contradicts the European Convention in a way that even Hungary or Poland have not yet done. ${ }^{15}$

Of course, there is no obligation for a writer to be exact regarding political institutions: George Orwell's Big Brother world was no more realistic than Houellebecq's world in Soumission. However, Orwell was writing at a time when democracy was in turmoil and the political institutions in Europe were not yet in place, and he sought to focus on the individual response to suppression rather than on the mechanism that paved the way for it. The novel 1984 came out in 1949, the year before the European Convention was adopted. In addition, the only tribunals for international rights that 
had occurred at that time were the Nuremberg trials that followed the end of the Second World War.

The current French left is not leaning away from nationalism; the small groups that are embracing a globalist and multicultural France in its deepest sense have had no access to parliaments, whether local or national. On the contrary, younger voters still hold on to secularist and republican values. ${ }^{16}$ Instead, both the intellectual debate and the political debate among leftists and liberals have stressed the importance of defending the secular state and the French laïcité, even if doing so means opposing the verdicts of the European Court. It is also interesting to note that the individualistic perspective in his novel prevents Houellebecq from discussing mobilization, civil society or academic bodies of any kind that could hinder his vision from coming true. Instead, we are presented with a political universe comprising uniquely strong men, one or two profiled women, oil-producing states, publishers and, finally, working men watching television. How would a takeover like the one described in Soumission take place with no political bodies? When Houellebecq discusses the election in which the left/liberal/Islamist alliance wins, he mentions public debates and reporting on the election in the media, but says very little about mobilization or opposition among the population itself (Ref. 17, pp. 44-47, 65-67).

Given the results of the many opinion polls that are conducted in France, a majority of the French population appears to prefer the Front National/Rassemblement National over any Islamists at all. ${ }^{18}$ Even if this is exactly the point Houellebecq wants to make - by rhetorically reversing the situation in a nearly deconstructivist way - the obvious fact is that the left and/or liberals would gain more votes by aligning with the nationalists than with the Islamists. Houellebecq stresses again and again that the Islamist leader in the novel, Ben Abbes, is moderate, smart, relentless and smooth. Nevertheless, this is not what wins elections. In fact, it strikes me that in this part of the novel, Houellebecq leaves the dystopia genre and instead reverts to a current political debate in France, a debate about the validity of the views of political elites and certain political figures, that tends to turn up in new guises every election. For example, Houellebecq mentions 'the old man from Béarn', which is a reference to François Bayrou, a centre politician who has led several political movements in France. He also mentions Marine le Pen (Front National/Rassemblement National) and Jean-François Copé (Républicains), individuals that represent themselves in this fictional book. Now and again in the novel, Houellebecq shows this inclination to take on a current debate; in my reading, this lack of self-control weakens the political value of his project. The end result is a mixture of fiction and vaguely masked facts that opens up the novel to several different and contradicting interpretations.

\section{Patriarchy as Politics}

Is there any advocacy for a political ideology in Soumission? Yes and no. The main theme in the book is patriarchy. Some readers may perceive the text as a critique of neo-patriarchy. Although there certainly are passages that can be politically interpreted in this way, the overwhelming picture is one in which patriarchy is a 
stabilizing force that conserves important elements of a good life. The novel also presents a picture that counters the modern-interest-based idea of society.

For Houellebecq, there seem to be no watertight bulkheads between organizing politics and organizing an individual life; both can be based on hedonism. Hedonism is what guides François when he evaluates the new principles influencing society after what might be called a putsch. In addition, hedonism is how politics is described in the book. For example, when François meets with his former colleague in that person's home - a very luxurious house with an ancient history - the presence of two wives (one 15 years old and one more mature, of unknown age) is described as an organizing principle for a good society: the younger wife is for pleasure in bed and to look upon, while the older wife makes good food and assists the men in the household. The two women are therefore more or less imprisoned in the family. Although François describes how women are forced away from most positions of power during the new regime, he simultaneously seems to stress that these two types of women are part of the normal order for a good society.

It is also interesting to follow François' relations with women. His only relationship containing any kind of tenderness (aside from one specific passage describing the sexual act) is with a Jewish girl, Myriam, who leaves France for exile in Israel. This relationship is not a particularly romantic one, although it is described with more of an emotional touch than his relationships with other females in the novel. Myriam is doing the only thing a woman who wants to live her own life, without obeying, can do in the new situation: leave the country. However, as the author tells us, she has a harsh life in Israel, where terror and violence are part of daily reality. In contrast, such violence disappears from France altogether after the takeover, despite its prevalence during the elections.

Neo-patriarchy as a political ideology seems to lack any of the collective responsibilities that are usually associated with the older patriarchy, such as keeping a household with servants, having dinner parties, having a social life, raising children, supporting good schools, and assisting weaker relatives. In fact, the pater familias is conspicuous by his absence. Instead, the neo-patriarchy that François finds so rewarding is totally individualistic. The combination of a liberal individual lifestyle with the absolute freedom to choose what is most desirable, and the given superiority of the mature urban educated male, gives us the ideology of neo-patriarchy that Houellebecq seems to portray. European society has abandoned its traditional lifestyle and promoted individualism. In addition, following Houellebecq's view, a badly understood multi-culturalism is what allowed the cultivation of a society in which a neo-patriarchy could grow and thrive.

Neo-patriarchy is presented as an apolitical ideology. The author embodies the direct opposite of political institutions and the ways in which society builds politics, which is through interest-based mobilization and collectivism. In the novel, the welfare state is cut back severely, as welfare is better taken care of by families according to the new regime. Although this concept is not perfectly compatible with the individualistic hedonism that is proclaimed in other passages in the book, it indicates the author's idea of the family being the most important bearer of the common good. If the state itself resigns - due to neo-patriarchy - it takes the power of collective 
resource allocation with it. This reasoning aligns well with another idea in Soumission - the idea that Ben Abbes and the new regime want to create a new 'true' European empire that, if I read the described geographical frontiers correctly, follows the shape of the Roman Empire. Neo-patriarchy is therefore an ideology that fits well with anti-nationalism (or imperialism, as it might be called). Neo-patriarchy also aligns very smoothly with populist rhetoric about law and order: there is only one people and only one authority (the male); and there is no legitimate political elite to decide for the many.

\section{The Materialist and Hedonist Views}

François is slightly obsessed with things - he may not have that many, but he describes them very carefully. He is the same when it comes to women. Women, cars, boots, food and wine are things to François - things by which he can enjoy the pleasures that (according to my own interpretation of the book) are presented as giving a man's life its absolute fulfilment.

Two very interesting moments of spiritual presence are important in this interpretation, which were mentioned earlier: the moment of desacralization in the church in Rocamadour and the visit to the monastery. François seems to be trying to find some power to resist something spiritual deep in himself; however, something betrays him on both occasions. In the first case, he sits down in front of the Virgin Mary and literally feels how the power from her - that he tended to believe in - is taken away from him. At the end, he is reduced to his own corruptible body, and the bench he is sitting on is suddenly just a simple, hard, ugly bench. François stands up and walks away as if he has been released. In the second instance, François tries to find spiritual contact at the monastery he had visited during his doctoral studies. He finds, however, that the monk he met at that time is no longer as friendly as in the past, and has transformed into one of the mature and highly respected monks in the monastery. Moreover, François notices a smoke detector in the ceiling. This observation irritates him, perhaps because the constraint it places on the pleasure of smoking or as a sign of modern rationality, and prompts him to return to Paris much earlier than he had planned to.

The description of food is generous when François eats and drinks; however, food is most generously described when François drinks good French wines and spirits and eats traditional French food. It is not possible to interpret the food narratives as anything other than a sort of nationalist poetry. However, food can also cancel a narrative: François waits for food, and when it comes, one of the many women in the book leaves him. Instead, he eats for hours, and the pleasure of it keeps him from doing what he had decided to do.

A materialist perspective is present in most of the relationships François has, regardless of the nature of the relationship. His parents, who both die during the novel, hold nothing but a material value for him, and he sees his father's late life with a new younger woman and a new car (a jeep) as something to be admired and emulated. His car and his food, his flat and his women, his books and his boots - these relations are strictly materialistic, and all are expected to give François pleasure. 


\section{Concluding Remarks}

The most striking element in Soumission is its individualistic perspective. Although Houellebecq describes a societal shock and a political putsch by a more or less totalitarian regime, all the observations are made by one male character and touch only on the universe in which this man lives his life. In one of the most interesting passages in the novel, François has decided to leave Paris after the takeover; however, he is held up in the southwest of France, a region where le confit de canard is a traditional dish, by a friend who offers him dinner. During conversation over this dinner, François is slowed down so much that he becomes incapable of continuing to escape. Instead, he returns to Paris, where he is offered a position in the new university regime, on the condition that he converts to Islam. This possible conversion fills François with some kind of spiritual hope; nevertheless, the most important consequence is that he can look forward to the earthly rewards of glory, pleasure and stability.

Although Soumission is political, most of the descriptions and discussions are politically naïve and oversimplified. The most interesting aspect of the text from a political scientist's point of view is the focus on materialism. In this narrative, materialism fuses with the search for some kind of faith; however, François finds himself to be both an object and subject of submission. In his possible conversion to Islam, François seems to finally manage to merge his hedonism with his search for a spiritual frame. Here, Islam as a tradition is portrayed as the perfect vessel for a political blend of male hedonism and neo-patriarchy.

It is also noteworthy that an ideal model for politics for François is one that appears to be as apolitical as possible. ${ }^{19}$ The nation state and its authority, the borders between peoples and territories, the election procedures, the political system and the collective good are all totally sidestepped in this dystopia. We are given a persuasive pamphlet for a neo-patriarchal and hedonistic male empire - an empire that is supposed to give everyone what is postulated as most important in this thinking: stability, gusto and traditional food. Most importantly, it seems, the new empire will guarantee that le confit de canard will be served forevermore.

\section{References and Notes}

1. G. Orwell (1949) 1984: A Novel (London: Signet classics).

2. P. Wilkin (2013) George Orwell: the English dissident as Tory anarchist. Political Studies, 61, pp. 197-214.

3. S. Ingle (2006) The Social and Political Thought of George Orwell: A Reassessment (London: Routledge).

4. P. Réage (1954) Histoire d'O (Paris: Editions Pauvert).

5. I have mainly read the book in the Swedish translation by Kristoffer Leandoer (Stockholm: Albert Bonniers, 2015).

6. O. Wievorka (2013) Histoire de la Résistance 1940-45 (Paris: Perrin).

7. A. Camus (1942) L'Étranger (Paris: Gallimard).

8. For a discussion of the so-called War of the Writers, see S. Unger (2001) Vichy: Beyond the syndrome syndrome? French Politics, Culture \& Society, 19(1), pp. $82-87$.

9. A. Camus (1942) Le mythe de Sisyphe (Paris: Gallimard). 
10. S. Unger (2001) Vichy: Beyond the syndrome syndrome? French Politics, Culture \& Society, 19(1).

11. Joris-Karl Huysmans was a French novelist known for his satire, wit and use of the French language. Among other things, he wrote an autobiographical trilogy with a main character who converts to Catholicism.

12. By saying that François Hollande was the man who should be re-elected with Islamic support, Houellebecq displays his naive idea of politics. The novel's argument goes as follows: President Hollande is weak and eager to uphold his power; therefore, he is a figure who may be able to invigorate the Islamic takeover in France. Nevertheless, no one in France in 2014-2015 would have thought that François Hollande could gain any popularity through Islamic/left/liberal views; in fact, they would have thought the exact opposite. The only ways for François Hollande to be re-elected would have been for him to either lean to the right of the political spectrum (i.e. toward law and order, or nationalism) or lean to the left in the old sense of resource allocation (i.e. the economy and labour market).

13. See, for example, an opinion article by Nabila Ramdani, The Guardian, 23 May 2010.

14. See, for example, arguments in R. Brubaker (2017) Between nationalism and civilizationism: The European populist moment in comparative perspective. Ethnic and Racial Studies, 40(8), pp. 1191-1226, DOI:10.1080/01419870.2017. 1294700

15. See, for example, the Freedom House report on Hungary 2017 (partly free) and the EU Press release 13 July 2017 on Hungary's new law on NGOs.

16. An empirical study supporting this statement is presented in B. O'Sullivan (2017) Reconciling the French Dilemma: Attitudes of the French Millennial Generation towards Maghrebi Immigration and Assimilation in France. Honours Thesis in Sociology, Whitman College, 10 May 2017.

17. M. Houellebecq (2015) Underkastelse, translated by Kristoffer Leandoer (Stockholm: Albert Bonniers förlag).

18. The IFOP Poll from 29 April 2016 showed that $47 \%$ of the French population thought that the Muslim community in France was a threat to national identity; this can be compared with the election result for the Front National in the first round on 18 June 2017, which was $13.2 \%$.

19. Here, politics is used as a concept for the authoritative allocation of values in a society, in line with D. Easton (1953) The Political System. An Inquiry into the State of Political Science (New York: Knopf).

\section{About the Author}

Marie Demker is a professor of political science at the University of Gothenburg, and Dean of the Faculty of Arts. Her main areas of research are political parties, religion and politics, and nationalism in Europe. For a couple of years, Demker has been studying the impact of new political cleavages on democratic development and mobilization. Her most recent publications in English are 'Religious liberty in democracy: Between individual tolerance and democratic inclusion', Nordic Journal of Religion and Society, 2016:1 pp. 18-35), and 'Media and the power of naming: An experimental study of racist, xenophobic and nationalist party labels' (Ethnicities, 2017, 17(5), pp. 727-745). In 2014, Demker co-authored Culture, Health, and Religion at the Millennium: Sweden Unparadised. 